\title{
Preparation and Characterization of Cu-doped TiO2 nanomaterials with Anatase/rutile/brookite Triphasic Structure and their Photocatalytic Activity
}

\section{Xiaodong Zhu}

Chengdu University

Qin Zhou

Chengdu University

\section{Yangwen Xia}

Chengdu University

\section{Juan Wang}

Chengdu University

\section{Hongjin Chen}

Chengdu University

Qiao Xu

Chengdu University

Jiawei Liu

Chengdu University

Wei Feng ( $\square$ fengwei233@126.com )

Chengdu University https://orcid.org/0000-0002-4318-8520

\section{Shanhua Chen}

Chengdu University of Technology

\section{Research Article}

Keywords: $\mathrm{Cu}-\mathrm{TiO} 2$, triphasic structure, photocatalytic activity, rhodamine $\mathrm{B}$

Posted Date: June 14th, 2021

DOl: https://doi.org/10.21203/rs.3.rs-262894/v1

License: (c) (1) This work is licensed under a Creative Commons Attribution 4.0 International License.

Read Full License

Version of Record: A version of this preprint was published at Journal of Materials Science: Materials in Electronics on July 26th, 2021. See the published version at https://doi.org/10.1007/s10854-021-06660- 
Page 2/24 


\section{Abstract}

Pure $\mathrm{TiO}_{2}$ and different concentrations of $\mathrm{Cu}$-doped $\mathrm{TiO}_{2}$ with anatase/rutile/brookite triphasic structure were successfully synthesized through a simple hydrothermal process and characterized by $\mathrm{X}$-ray diffraction (XRD), Raman, scanning electron microscope (SEM), transmission electron microscope (TEM), $X$-ray photoelectron spectra (XPS), diffuse reflectance spectra (DRS), photoluminescence spectra (PL) and Brunauer-Emmett-Teller surface area (BET). Both pure and $\mathrm{Cu}$-doped $\mathrm{TiO}_{2}$ show relatively high photocatalytic activity owing to their considerable surface areas. Moreover, the three-phase coexisting structure and the conversion between $\mathrm{Cu}^{2+}$ and $\mathrm{Cu}^{+}$ions facilitate the separation of photogenerated electrons and holes, which is favorable for photocatalytic performance. $1 \% \mathrm{Cu}-\mathrm{TiO}_{2}$ exhibits the highest photocatalytic activity and the degradation degree of rhodamine $B(\mathrm{RhB})$ reaches $93.5 \%$ after $30 \mathrm{~min}$, which is higher than that of monophasic/biphasic $1 \% \mathrm{Cu}-\mathrm{TiO}_{2} \cdot \mathrm{O}_{2}{ }^{-}$radical is the main active specie, and $\mathrm{h}^{+}$and $\cdot \mathrm{OH}$ are subsidiary in the degradation process.

\section{Introduction}

Degradation of water pollutants by photocatalysts is a promising technology because of its environmental protection and validity [1-3]. Several candidate photocatalysts have been used in water treatment such as $\mathrm{ZnO}$ [4, 5], $\mathrm{SrTiO}_{3}$ [6], $\mathrm{CdS}$ [7] and so on. Among many different photocatalysts, $\mathrm{TiO}_{2}$ materials are extensively investigated due to its high chemical stability, high efficiency, availability and nontoxicity [8-12]. However, $\mathrm{TiO}_{2}$ absorbs only ultraviolet light which is less than $5 \%$ of sunlight. Besides, the high recombination rate of photoinduced charge carriers is another drawback [1,2]. It is necessary to modify it and metal ions doping is a simple and effective modification way. It has been widely reported that $\mathrm{Cu}$ doping can modify the structure of $\mathrm{TiO}_{2}$ and enhance the photocatalytic activity $[13,14]$.

There are three crystal phases of $\mathrm{TiO}_{2}$ : anatase, rutile and brookite. Anatase $\mathrm{TiO}_{2}$ or rutile $\mathrm{TiO}_{2}$ has been synthesized by various methods and their photocatalytic performance is widely studied. In addition, a lot of researches focus on preparing mixed phase $\mathrm{TiO}_{2}$ with excellent photocatalytic activity. The reason for the higher photocatalytic activity of mixed phase $\mathrm{TiO}_{2}$ than single-phase $\mathrm{TiO}_{2}$ is that the conduction band positions of the three phases are different. Therefore, photogenerated electrons can move from the phase with higher conduction band to the phase with lower conduction band, inhibiting the recombination of photogenerated electrons and holes and improving the quantum efficiency $[12,15]$. For instance, $\mathrm{Li}$ et al. [15] successfully synthesized $\mathrm{TiO}_{2}$ photocatalysts with different proportions of anatase and rutile mixed phases in an acidic hydrothermal system. The photodegradation of rhodamine $B(\mathrm{RhB})$ and methyl orange $(\mathrm{MO})$ results show that the mixed phase $\mathrm{TiO}_{2}$ samples display better photocatalytic performance, and the catalyst containing $77 \mathrm{wt}$. \% anatase and $23 \mathrm{wt}$. \% rutile exhibits the highest photocatalytic activity. Cao et al. [16] prepared brookite $\mathrm{TiO}_{2}$ with different rutile contents by a facile solvothermal method. $\mathrm{TiO}_{2}$ consisted of $28 \mathrm{wt}$. \% rutile and $72 \mathrm{wt}$ \% brookite exhibits the highest degradation rate. The researches on $\mathrm{TiO}_{2}$ with anatase/rutile/brookite triphasic structure have also been 
reported $[10,17]$. Based on two-phase mixed $\mathrm{TiO}_{2}$, since the conduction band position of brookite is higher than those of anatase and rutile, the three-phase mixed structure can further accelerate the migration of photogenerated electrons at the phase interfaces, which is beneficial to higher photocatalytic performance [10]. Kaplan et al. [17] prepared $\mathrm{TiO}_{2}$ with anatase, rutile and brookite polymorph phases by combining sol-gel process and hydrothermal treatment. It has been proved that $\mathrm{TiO}_{2}$ with triphasic structure exhibits better photocatalytic activity than anatase or rutile.

It is widely recognized that the specific surface area of photocatalysts is an important factor to photocatalytic performance. Many studies have been devoted to improving photocatalytic activity by increasing the specific surface area of $\mathrm{TiO}_{2}$. The results of Aguilar et al.'s work reveal that the photocatalytic activity is enhanced owing to the increase of specific surface area after Cu doping [18]. It is reported by Zhang et al. [19] that the specific surface area of P25 increases from $55.7 \mathrm{~m}^{2} / \mathrm{g}$ to 78.7 $\mathrm{m}^{2} / \mathrm{g}$ after combining with graphene, consequently, the photocatalytic performance is extremely improved.

In the present study, pure and $\mathrm{Cu}$-doped $\mathrm{TiO}_{2}$ nanocomposites with anatase/brookite/rutile triphasic structure were prepared by a facile hydrothermal method. The prepared samples were systematically characterized and their photocatalytic activity was assessed through the decomposition of RhB under xenon lamp irradiation.

\section{Experimental}

\subsection{Synthesis of pure and $\mathrm{Cu}-$ doped $\mathrm{TiO}_{2}$ nanomaterials}

$5 \mathrm{~mL}$ butyl titanate was dissolved into $10 \mathrm{~mL}$ ethanol to obtain solution A. $1 \mathrm{~mL}$ hydrochloric acid (37\%), $1 \mathrm{~mL}$ polyethylene glycol (600) and proper amounts copper nitrate trihydrate $(0.036 \mathrm{~g}, 0.072 \mathrm{~g}, 0.108 \mathrm{~g}$ and $0.144 \mathrm{~g}$ ) were dissolved into $15 \mathrm{~mL}$ distilled water to acquire solution B. Solution B was added dropwise into solution $A$ to form a sol.

The obtained sol mixture was transferred into a polytetrafluoroethylene-lined autoclave. The temperature and time of hydrothermal treatment were $180^{\circ} \mathrm{C}$ and $12 \mathrm{~h}$. After the reactions, samples were washed and dried at $100^{\circ} \mathrm{C}$ and finally $\mathrm{Cu}$-doped $\mathrm{TiO}_{2}$ nanocomposites were obtained. The $\mathrm{Cu} / \mathrm{Ti}$ molar ratios are $1 \%$, $2 \%, 3 \%$ and $4 \%$. For simplicity, $x \mathrm{Cu}$-doped $\mathrm{TiO}_{2}(x=1 \%, 2 \%, 3 \%$ and $4 \%)$ is labelled as $x \mathrm{Cu}-\mathrm{TiO}_{2}(x=1 \%$, $2 \%, 3 \%$ and $4 \%$ ). Pure $\mathrm{TiO}_{2}$ nanocrystalline can be obtained without adding copper nitrate trihydrate in solution B.

\subsection{Characterization}

$X$-ray diffraction (XRD) patterns were recorded with a diffractometer (DX-2700, China). The test voltage is $40 \mathrm{kV}$, the test current is $30 \mathrm{~mA}$, the scanning speed is $0.06 \%$, and the scanning angle is $20^{\circ}-70^{\circ}$. Raman spectra were measured using a Micro-Raman Renishaw spectrometer (Andor SR-500i, Britain) 
equipped with an argon laser $(532 \mathrm{~nm})$. The surface morphologies were determined by a field-emission scanning electron microscope with a working voltage of $5 \mathrm{kV}$ (SEM, FEI-Inspect F50, USA) and a transmission electron microscope with an acceleration voltage of $200 \mathrm{kV}$ (TEM and HRTEM, FEI-Tecnai G2 F20, USA). X-ray photoelectron spectra (XPS) were recorded using a spectrometer using Mg ka at 12 $\mathrm{kV}$ and $12 \mathrm{~mA}$ (XSAM800, Britain). The optical properties were tested by UV-Vis diffuse reflectance spectra from 200-800 nm (DRS, UV-3600 spectrophotometer, Japan) and photoluminescence spectra (PL, F-4600 spectrophotometer with a $150 \mathrm{~W}$ xenon lamp (excitation wavelength $300 \mathrm{~nm}$ ), Japan). A Vsorb 2800 S surface area analyzer (China) was used to measure the BET specific surface area. The pore size distribution and pore volumes were obtained using the Barrett-Joyner-Halenda (BJH) method.

\subsection{Photocatalytic test}

The photocatalytic property of the obtained photocatalysts was evaluated through the degradation of $\mathrm{RhB}$ in aqueous solution. $100 \mathrm{~mL} \mathrm{RhB}$ solution $(10 \mathrm{mg} / \mathrm{L})$ and $0.1 \mathrm{~g}$ photocatalyst powder were added into a beaker, and then stirred $30 \mathrm{~min}$ in dark. Afterwards, a $250 \mathrm{~W}$ xenon lamp with the emission wavelength from $300 \mathrm{~nm}$ to $800 \mathrm{~nm}$ was turned on as light source. The degradation of RhB was tested by measuring the absorbance at $553 \mathrm{~nm}$ every $10 \mathrm{~min}$. The degradation degree $(D)$ was determined by the formula as follows:

$D=\left(A_{0}-A_{t}\right) / A_{0}$, where $A_{0}$ and $A_{t}$ are the initial absorbance and absorbance at time " $\mathrm{t}$ ", respectively.

\section{Results And Discussion}

\subsection{XRD analysis}

Figure 1 exhibits the XRD patterns of pure $\mathrm{TiO}_{2}$ and $\mathrm{Cu}-\mathrm{TiO}_{2}$. For both pure $\mathrm{TiO}_{2}$ and $\mathrm{Cu}-\mathrm{TiO}_{2}$ samples, the diffraction peaks appear at $2 \theta=25.3^{\circ}, 37.7^{\circ}$ and $48.0^{\circ}$, ascribing to the (101), (004) and (200) crystal planes of anatase structure (JCPDS $21-1272$ ). Meanwhile, peaks at $27.4^{\circ}, 36.1^{\circ}$ and $54.3^{\circ}$ can be attributed to the (110), (101) and (211) planes of rutile $\mathrm{TiO}_{2}$ (JCPDS 21-1276). Furthermore, the peaks appear at $2 \theta=25.2^{\circ}, 25.4^{\circ}$ (overlapping with anatase (101) plane) and $30.8^{\circ}$, corresponding to the (120), (111) and (121) crystal planes of brookite $\mathrm{TiO}_{2}$ (JCPDS 29-1360). The simultaneous appearance of the diffraction peaks corresponding to anatase, rutile and brookite structures indicates that the three phases coexist in both pure $\mathrm{TiO}_{2}$ and $\mathrm{Cu}-\mathrm{TiO}_{2}$. The mass fractions of anatase $(W a)$, brookite $(W b)$ and rutile $(W r)$ can be calculated as follows:

$W a=K a A a /(K a A a+A r+K b A b)$

$W b=K b A b /(K a A a+A r+K b A b)$

$W r=A r /(K a A a+A r+K b A b)$

where $K a(0.886)$ and $K b(2.721)$ are correction coefficients. $A a, A b$ and Arexpress the peak intensities of anatase (101), brookite (121) and rutile (110) planes, respectively [20, 21]. The crystallite size was 
calculated by Scherrer's formula. For anatase, rutile and brookite, $\beta$ are the half widths of the diffraction peaks of anatase (101), rutile (110), and brookite (121) planes, respectively [22, 23]. The phase composition and the average crystallite size of samples are summarized in Table 1. It can be seen that the content of anatase decreases and the content of rutile increases after $\mathrm{Cu}$ doping, which shows that the addition of $\mathrm{Cu}$ is conducive to the transformation from anatase to rutile. Since $\mathrm{Cu}^{2+} / \mathrm{Cu}^{+}$ion radius $(0.073 / 0.077 \mathrm{~nm})$ is close to $\mathrm{Ti}^{4+}$ ion radius $(0.0605 \mathrm{~nm}), \mathrm{Cu}^{2+} / \mathrm{Cu}^{+}$can enter into $\mathrm{TiO}_{2}$ lattice to replace $\mathrm{Ti}^{4+}$ ions and does not react with $\mathrm{TiO}_{2}$ to generate new crystal phase. This is in line with the earlier literatures $[1,13,14]$. When reaching a certain concentration, the Cu element is dispersed in the form of oxide on the surface of $\mathrm{TiO}_{2}$ particles. Therefore, the Cu-related diffraction peak cannot be detected in XRD patterns.

Table 1

Phase composition and average crystallite size of pure $\mathrm{TiO}_{2}$ and $\mathrm{Cu}-\mathrm{TiO}_{2}$.

\begin{tabular}{|llll|}
\hline Photocatalysts & \multicolumn{3}{l|}{ Phase composition (\%) / Crystallite size (nm) } \\
\cline { 2 - 4 } & Anatase/Crystallite size & Rutile/Crystallite size & Brookite/Crystallite size \\
\hline pure $\mathrm{TiO}_{2}$ & $59.0 \% / 9.2$ & $21.4 \% / 21.4$ & $19.6 \% / 13.0$ \\
\hline $1 \% \mathrm{Cu}-\mathrm{TiO}_{2}$ & $43.4 \% / 9.4$ & $32.8 \% / 19.4$ & $23.8 \% / 12.3$ \\
\hline $2 \% \mathrm{Cu}-\mathrm{TiO}_{2}$ & $36.2 \% / 10.2$ & $46.0 \% / 27.3$ & $17.8 \% / 11.9$ \\
\hline $3 \% \mathrm{Cu}-\mathrm{TiO}_{2}$ & $50.6 \% / 9.4$ & $25.8 \% / 20.5$ & $23.6 \% / 11.8$ \\
\hline $4 \% \mathrm{Cu}-\mathrm{TiO}_{2}$ & $37.2 \% / 9.9$ & $39.6 \% / 27.7$ & $23.2 \% / 18.7$ \\
\hline
\end{tabular}

\subsection{Raman analysis}

To further confirm the crystal structure of the as-prepared samples, Raman measurement has been employed to distinguish the three structures of $\mathrm{TiO}_{2}$ and the results are shown in Fig. 2. The intense Raman bands located at $398 \mathrm{~cm}^{-1}, 517 \mathrm{~cm}^{-1}$ and $640 \mathrm{~cm}^{-1}$ ascribe to anatase structure $[14,17]$. The bands centered at $244 \mathrm{~cm}^{-1}$ and $444 \mathrm{~cm}^{-1}$ can be attributed to rutile structure, while the bands centered at $320 \mathrm{~cm}^{-1}$ and $363 \mathrm{~cm}^{-1}$ are for brookite structure $[10,16,17]$. The Raman spectra confirm that there are anatase/rutile/brookite three phases coexistence in pure $\mathrm{TiO}_{2}$ and $\mathrm{Cu}-\mathrm{TiO}_{2}$, which is in line with XRD results.

\subsection{SEM and TEM analyses}

Figure 3 depicts the SEM images of pure $\mathrm{TiO}_{2}(\mathrm{a})$ and $1 \% \mathrm{Cu}-\mathrm{TiO}_{2}(\mathrm{~b})$. It is observed that pure $\mathrm{TiO}_{2}$ consists of nanoparticles and a few nanorods. $1 \% \mathrm{Cu}-\mathrm{TiO}_{2}$ is also made of nanoparticles and nanorods. 
The TEM image of $1 \% \mathrm{Cu}-\mathrm{TiO}_{2}$ is shown in Fig. $3 \mathrm{c}$, which reveals that the particles size in $1 \% \mathrm{Cu}-\mathrm{TiO}_{2}$ ranges from 10 to $20 \mathrm{~nm}$. The nanorods in $1 \% \mathrm{Cu}-\mathrm{TiO}_{2}$ have a length of $100 \mathrm{~nm}$ and a width of $10 \mathrm{~nm}$ approximately. Figure $3 \mathrm{~d}$ presents the HRTEM image of $1 \% \mathrm{Cu}-\mathrm{TiO}_{2}$. The marked lattice distances are $0.353 \mathrm{~nm}, 0.250 \mathrm{~nm}$ and $0.293 \mathrm{~nm}$, which can be attributed to the (101) crystal plane of anatase, the (101) crystal plane of rutile and the (121) crystal plane of brookite [24], respectively. Figure 3e-j present the STEM mapping of $1 \% \mathrm{Cu}-\mathrm{TiO}_{2}$. It can be seen that there are three elements $(\mathrm{Ti}, \mathrm{O}, \mathrm{Cu})$ in the sample and are distributed in the matrix basically evenly.

\subsection{XPS analysis}

Figure 4 shows the XPS results of pure $\mathrm{TiO}_{2}$ and $1 \% \mathrm{Cu}-\mathrm{TiO}_{2}$. Total spectra are displayed in Fig. $4 \mathrm{a}$, from which the signals of $\mathrm{Ti}, \mathrm{O}$ and $\mathrm{C}$ elements can be detected in pure $\mathrm{TiO}_{2}$. Meanwhile, a peak of $\mathrm{Cu} 2 \mathrm{p}$ appears in $1 \% \mathrm{Cu}-\mathrm{TiO}_{2}$ spectrum, which confirms that $\mathrm{Cu}$ exists in $\mathrm{TiO}_{2}$ via doping. Figure $4 \mathrm{~b}$ shows the high-resolution spectra of $\mathrm{Ti} 2 \mathrm{p}$. The spectrum of pure $\mathrm{TiO}_{2}$ has two peaks at $464.2 \mathrm{eV}$ and $458.4 \mathrm{eV}$ corresponding to Ti $2 p_{1 / 2}$ and $\mathrm{Ti} 2 p_{3 / 2}$, suggesting that the chemical state of Ti element is +4 [2]. Similarly, two peaks at $463.8 \mathrm{eV}$ and $458.1 \mathrm{eV}$ in the spectrum of $1 \% \mathrm{Cu}-\mathrm{TiO}_{2}$, which means $\mathrm{Ti}$ ions exist as $\mathrm{Ti}^{4+}$. The high-resolution spectra of $01 \mathrm{~s}$ are shown in Fig. 4c. The peaks include lattice oxygen $\left(\mathrm{O}_{\mathrm{L}}\right)$ peak at $530.0 \mathrm{eV}$ and surface hydroxyl groups $\left(\mathrm{O}_{\mathrm{H}}\right)$ peak at $532.2 \mathrm{eV}$ in pure $\mathrm{TiO}_{2}[1,25,26]$. The peaks for $\mathrm{O}_{\mathrm{L}}$ and $\mathrm{O}_{\mathrm{H}}$ of $1 \% \mathrm{Cu}-\mathrm{TiO}_{2}$ are situated at $529.5 \mathrm{eV}$ and $532.0 \mathrm{eV}$, separately. In photodegradation process, $\mathrm{Z} O H$ radicals are formed as the results of the reaction between surface hydroxyl groups and photoinduced holes, which possess strong oxidation ability. Therefore, more surface hydroxyl groups are beneficial to photocatalytic activity $[27,28]$. The ratio of surface hydroxyl groups can be calculated from the deconvolution area of the two peaks [28]. The integral areas of $\mathrm{O}^{2-}\left(\mathrm{O}_{\mathrm{L}}\right)$ and $\mathrm{OH}^{-}\left(\mathrm{O}_{\mathrm{H}}\right)$ peaks are 46638 and 7391 in pure $\mathrm{TiO}_{2}$ and the proportion of $\mathrm{O}_{\mathrm{H}}$ is $7391 /(46638+7391)=13.7 \%$. The integral areas of $\mathrm{O}_{\mathrm{L}}$ and $\mathrm{O}_{\mathrm{H}}$ peaks are 45270 and 8666 in $1 \% \mathrm{Cu}-\mathrm{TiO}_{2}$ and the proportion of $\mathrm{O}_{\mathrm{H}}$ is $8666 /(45270+$ $8666)=16.1 \%$. The calculation results are convinced that the surface hydroxyl group ratio increases after $\mathrm{Cu}$ doping. Compared to the $\mathrm{Ti} 2 \mathrm{p}$ and $\mathrm{O} 1$ s peaks of pure $\mathrm{TiO}_{2}$, the peaks of $1 \% \mathrm{Cu}-\mathrm{TiO}_{2}$ shift to lower binding energy, which proves the formation of Ti-O-Cu bonds $[1,25]$. The shift to lower binding energy probably because there is a shift in electron density from a lower electronegative $\mathrm{Ti}$ (1.54, Pauling value) to a higher electronegative $\mathrm{Cu}(1.90$, Pauling value) atom [8]. Figure $4 \mathrm{~d}$ displays the high-resolution spectrum $\mathrm{Cu} 2 \mathrm{p}$ of $1 \% \mathrm{Cu}-\mathrm{TiO}_{2}$. It is observed that the peaks for $\mathrm{Cu}^{2+}$ are located at 933.4 and $952.3 \mathrm{eV}$ and the peak for $\mathrm{Cu}^{+}$is located at $957.8 \mathrm{eV}$. The peak at $943.7 \mathrm{eV}$ is related to the shock peak of $\mathrm{CuO}[29$, 30].

\subsection{DRS analysis}

The diffuse reflectance spectroscopy test was carried out to examine the optical property of obtained photocatalysts and the DRS spectra are exhibited in Fig. 5a. The Kubelka-Munk function for diffuse reflectance is $F(R)=(1-R)^{2} / 2 R[18]$. Because $\mathrm{F}(\mathrm{R})$ is proportionality to the absorption coefficient $\mathrm{a}$, it can be obtained according to the Tauc's formula [31-33]. The plots of (ahv) ${ }^{1 / 2}$ versus the photon energy (hv) 
were demonstrated in Fig. $5 \mathrm{~b}$. The band gap energy values of pure $\mathrm{TiO}_{2}, 1 \% \mathrm{Cu}-\mathrm{TiO}_{2}, 2 \% \mathrm{Cu}-\mathrm{TiO}_{2}, 3 \% \mathrm{Cu}-$ $\mathrm{TiO}_{2}$ and $4 \% \mathrm{Cu}-\mathrm{TiO}_{2}$ are $3.06 \mathrm{eV}, 3.07 \mathrm{eV}, 3.02 \mathrm{eV}, 2.96 \mathrm{eV}$ and $3.04 \mathrm{eV}$, separately. It is worth noting that the absorption of $2 \% \mathrm{Cu}-\mathrm{TiO}_{2}$ and $3 \% \mathrm{Cu}-\mathrm{TiO}_{2}$ in the ultraviolet region is lower than that of the pure sample, which hinders the absorption of the light source and is not conducive to photocatalytic activity.

\subsection{PL analysis}

Since photoluminescence emission is derived from the recombination of photoinduced holes and electrons, it can provide accurate data of the separation of photoinduced pairs [34-36]. The PL spectra of pure $\mathrm{TiO}_{2}$ and $\mathrm{Cu}-\mathrm{TiO}_{2}$ are shown in Fig. 6 and it is found that the addition of $\mathrm{Cu}$ does not bring new emission peak but only changed the peak intensity. The main peaks around $412 \mathrm{~nm}$ can be ascribed to the band gap transition [36, 37]. The peaks arranged from $450 \mathrm{~nm}$ to $470 \mathrm{~nm}$ are attributed to the transition of charge carriers $[36,38]$. All the $\mathrm{Cu}-\mathrm{TiO}_{2}$ samples show lower peak intensity than pure $\mathrm{TiO}_{2}$, which indicates that the recombination of photoinduced electrons and holes is hindered by $\mathrm{Cu}$ adding effectively. Remarkably, the PL intensity decreases with the increase of Cu concentration, implying that the higher doping amount is, the more favorable it is to suppress the recombination of photogenerated electrons and holes.

\subsection{BET analysis}

Figure 7 presents the $\mathrm{N}_{2}$ adsorption-desorption isotherms and the pore size distribution curves (inset of Fig. 7) of pure $\mathrm{TiO}_{2}$ and $\mathrm{Cu}-\mathrm{TiO}_{2}$. All the photocatalysts exhibit the type IV isotherms with the $\mathrm{H} 2$ hysteresis loop in the range of high relative pressure, which are the characteristic of mesoporous materials $(2-50 \mathrm{~nm})[1,10,27,37,39]$. The pore size distribution curves indicate that both pure $\mathrm{TiO}_{2}$ and $\mathrm{Cu}-\mathrm{TiO}_{2}$ have a narrow pore size distribution and the main pore diameters are ranged from $3 \mathrm{~nm}$ to $9 \mathrm{~nm}$. The specific surface area, pore size and pore volume data are listed in Table 2. The specific surface area results reveal that $\mathrm{Cu}-\mathrm{TiO}_{2}$ samples show higher surface areas than pure $\mathrm{TiO}_{2}$. Sibu et al. [40] and Adyani et al. [1] believe that the surface textural property is improved owing to the presence of $\mathrm{Ti}-\mathrm{O}-\mathrm{M}$ ( $\mathrm{M}$ is the doping element) bonds, which may restrain the conformity and rearrangement of the primary crystals, leading to increase of surface area [26, 33]. 
Table 2

Textural properties of pure $\mathrm{TiO}_{2}$ and $\mathrm{Cu}-\mathrm{TiO}_{2}$.

\begin{tabular}{|llll|}
\hline Photocatalysts & BET surface area $\left(\mathbf{m}^{2} / \mathbf{g}\right)$ & $\begin{array}{l}\text { Pore volume } \\
\left(\mathbf{c m}^{3} / \mathbf{g}\right)\end{array}$ & Average pore size $(\mathrm{nm})$ \\
\hline pure $\mathrm{TiO}_{2}$ & 140.8 & 0.286 & 6.9 \\
\hline $1 \% \mathrm{Cu}-\mathrm{TiO}_{2}$ & 160.0 & 0.311 & 6.4 \\
\hline $2 \% \mathrm{Cu}-\mathrm{TiO}_{2}$ & 195.0 & 0.307 & 5.9 \\
\hline $3 \% \mathrm{Cu}-\mathrm{TiO}_{2}$ & 177.5 & 0.279 & 6.2 \\
\hline $4 \% \mathrm{Cu}-\mathrm{TiO}_{2}$ & 211.1 & 0.334 & 6.1 \\
\hline
\end{tabular}

\subsection{Photocatalytic activity analysis}

Figure 8a shows the degradation degree of $\mathrm{RhB}$ relative to pure $\mathrm{TiO}_{2}$ and $\mathrm{Cu}-\mathrm{TiO}_{2}$ under xenon lamp irradiation for $30 \mathrm{~min}$. RhB was not degraded under illumination without photocatalyst, implying that the degradation of RhB should be attributed to the photodegradation of photocatalysts. The degradation degrees of pure $\mathrm{TiO}_{2}, 1 \% \mathrm{Cu}-\mathrm{TiO}_{2}, 2 \% \mathrm{Cu}-\mathrm{TiO}_{2}, 3 \% \mathrm{Cu}-\mathrm{TiO}_{2}$ and $4 \% \mathrm{Cu}-\mathrm{TiO}_{2}$ are $90.0 \%, 93.5 \%, 91.8 \%$, $86.2 \%$ and $92.5 \%$, respectively. It is clear that all the photocatalysts show considerable photocatalytic activity, which attributes to relatively high specific surface areas $\left(>140 \mathrm{~m}^{2} / \mathrm{g}\right)$ and the anatase/rutile/brookite triphasic structure.

$1 \% \mathrm{Cu}-\mathrm{TiO}_{2}$ shows higher photocatalytic efficiency than pure $\mathrm{TiO}_{2}$ because of its less recombination rate and higher surface area compared to pure $\mathrm{TiO}_{2}$. However, as the amount of doping content increases, the degradation degrees slightly decrease in $2 \% \mathrm{Cu}-\mathrm{TiO}_{2}$ and $3 \% \mathrm{Cu}-\mathrm{TiO}_{2}$ samples. The effect of doping amount on suppressing the recombination of photoinduced pairs is controversial. Several studies show that there is an optimal concentration in doping, and the inhibition of photogenerated electrons and holes is weakened when the concentration exceeds the optimal value [41-43]. The authors believe that excessive doping content will generate new recombination centers, which is not conducive to the migration of photogenerated electrons and holes. Correspondingly, it has also been documented that the higher the doping amount, the higher inhibition effect [44-46]. The inconsistent results may be caused by different preparation methods and processes. In the present study, when the concentration of $\mathrm{Cu} / \mathrm{Ti}$ reaches $4 \%$, it is still conducive to the separation of photogenerated electrons and holes. Therefore, the decreased photocatalytic activity of $2 \% \mathrm{Cu}-\mathrm{TiO}_{2}$ and $3 \% \mathrm{Cu}-\mathrm{TiO}_{2}$ should not be ascribed to the enhancement of recombination rate. On the other hand, DRS results shows that the absorption of $2 \% \mathrm{Cu}-$ $\mathrm{TiO}_{2}$ and $3 \% \mathrm{Cu}-\mathrm{TiO}_{2}$ in the ultraviolet region is lower than that of the pure sample, which may be attributed to the fact that the excessive $\mathrm{Cu}$ doping content produce more $\mathrm{CuO}$ and $\mathrm{Cu}_{2} \mathrm{O}$ clusters on $\mathrm{TiO}_{2}$ surface, decreasing the light utilization and photocatalytic efficiency [44]. However, if the specific surface 
area further increases, the disadvantage caused by $\mathrm{CuO}$ and $\mathrm{Cu}_{2} \mathrm{O}$ covering $\mathrm{TiO}_{2}$ surface can be offset. Therefore, the photocatalytic efficiency of $4 \% \mathrm{Cu}-\mathrm{TiO}_{2}$ increases slightly since it possesses the highest specific surface area $\left(211.1 \mathrm{~m}^{2} / \mathrm{g}\right)$.

Figure $8 \mathrm{~b}$ displays the kinetics fitting curves of $\ln \left(C / C_{0}\right)=-k t$ of the photocatalysts [47]. The apparent first-order rate constants $k$ of pure $\mathrm{TiO}_{2}, 1 \% \mathrm{Cu}-\mathrm{TiO}_{2}, 2 \% \mathrm{Cu}-\mathrm{TiO}_{2}, 3 \% \mathrm{Cu}-\mathrm{TiO}_{2}$ and $4 \% \mathrm{Cu}-\mathrm{TiO}_{2}$ are 0.071 $\min ^{-1}\left(R^{2}=0.948\right), 0.091 \mathrm{~min}^{-1}\left(R^{2}=0.977\right), 0.083 \mathrm{~min}^{-1}\left(R^{2}=0.971\right), 0.063 \mathrm{~min}^{-1}\left(R^{2}=0.948\right)$ and $0.084 \mathrm{~min}^{-1}\left(R^{2}=0.992\right)$, respectively.

\subsection{The degradation mechanism}

$\mathrm{O}_{2}{ }^{-}$radicals react with nitro-blue tetrazolium (NBT) to form purple precipitates, therefore, the lower NBT absorbance indicates more $\cdot \mathrm{O}_{2}{ }^{-}$radicals generates. 2, 3-HBA is obtained by the reaction of salicylic acid $(\mathrm{SA})$ with $\cdot \mathrm{OH}$ radicals, which has a special absorption at $510 \mathrm{~nm}$. Therefore, the higher absorbance is, the higher the concentration of $2,3-\mathrm{HBA}$ is, indicating that more $\cdot \mathrm{OH}$ radicals are produced $[48,49]$. Taking $1 \% \mathrm{Cu}-\mathrm{TiO}_{2}$ as an example, the experiments are carried out. Figure $9 \mathrm{a}$ shows that the NBT absorbance decreases with increased illumination time, indicating that more and more purple precipitates are generated from the reaction between $\mathrm{O}_{2}{ }^{-}$and NBT after illumination, which results in the consumption of NBT. The decreasing NBT absorbance indicates that the photogenerated electrons are excited to the conduction band after illumination and react with $\mathrm{O}_{2}$ to form $\cdot \mathrm{O}_{2}{ }^{-}$radicals. Figure $9 \mathrm{~b}$ shows that 2, 3-HBA absorbance increases with the increased illumination time. Because 2, 3-HBA is obtained from the reaction between $\mathrm{SA}$ and $\cdot \mathrm{OH}$, the increasing $2,3-\mathrm{HBA}$ absorbance indicates that $\cdot \mathrm{OH}$ radicals are formed under illumination.

NBT and SA experiments confirm that $\cdot \mathrm{O}_{2}{ }^{-}$and $\cdot \mathrm{OH}$ radicals are generated under illumination. Since $\cdot \mathrm{O}_{2}{ }^{-}$ radicals come from the reaction of photogenerated electrons with $\mathrm{O}_{2}$, and $\cdot \mathrm{OH}$ radicals originate from the reaction of photogenerated hole with $\mathrm{OH}^{-}$, the numbers of $\cdot \mathrm{O}_{2}{ }^{-}$and $\cdot \mathrm{OH}$ radicals can be used to measure the separation of photogenerated charge under the same conditions. Figure 10a shows that the NBT absorbance of pure $\mathrm{TiO}_{2}$ is higher than that of $1 \% \mathrm{Cu}-\mathrm{TiO}_{2}$, which suggests that $1 \% \mathrm{Cu}-\mathrm{TiO}_{2}$ generates more $\cdot \mathrm{O}_{2}{ }^{-}$radicals than pure $\mathrm{TiO}_{2}$. Figure $10 \mathrm{~b}$ shows that the $2,3-\mathrm{HBA}$ absorbance of pure $\mathrm{TiO}_{2}$ is lower than that of $1 \% \mathrm{Cu}-\mathrm{TiO}_{2}$, indicating that $1 \% \mathrm{Cu}-\mathrm{TiO}_{2}$ produces more $\cdot \mathrm{OH}$ radicals. Therefore, $1 \% \mathrm{Cu}-\mathrm{TiO}_{2}$ shows the higher separation rate of photogenerated charges than pure $\mathrm{TiO}_{2}$. $\mathrm{Cu}$ doping enhances the quantum efficiency, which is consistent with the PL spectra.

In order to compare the photogenerated charge separation of triphasic photocatalysts and the monophasic/biphasic photocatalysts, the NBT and 2, 3-HBA absorbances of $1 \% \mathrm{Cu}-\mathrm{TiO}_{2}$ were measured and the results are shown in Fig. 11 . Compared to monophasic/biphasic $1 \% \mathrm{Cu}-\mathrm{TiO}_{2}$, triphasic $1 \% \mathrm{Cu}-$ $\mathrm{TiO}_{2}$ has lower NBT absorbance and higher 2, 3-HBA absorbance, which indicates that triphasic $1 \% \mathrm{Cu}-$ 
$\mathrm{TiO}_{2}$ produces more photogenerated charges and has the highest quantum efficiency. Accordingly, the photocatalytic activity of triphasic $1 \% \mathrm{Cu}-\mathrm{TiO}_{2}$ is higher than that of monophasic/biphasic $1 \% \mathrm{Cu}-\mathrm{TiO}_{2}$.

To determine the active species in the process of photodegradation, isopropanol (IPA), benzoquinone (BQ) and ammonium oxalate (AO) were added to capture $\cdot \mathrm{OH}, \mathrm{O}_{2}{ }^{-}$and $\mathrm{h}^{+}$, respectively. The degradation results of $1 \% \mathrm{Cu}-\mathrm{TiO}_{2}$ in the presence of different scavengers are shown in Fig. 12. When $\mathrm{BQ}, \mathrm{AO}$ and IPA were added, the degradation rate of $1 \% \mathrm{Cu}-\mathrm{TiO}_{2}$ decreases from $93.5-36.0 \%, 68.2 \%$ and $91.4 \%$, respectively. Obviously, the degradation rate is significantly decreased with $B Q$ adding. The degradation rate decreases slightly in the presence of $A O$ and IPA. Since BQ captures $\cdot \mathrm{O}_{2}{ }^{-}, \mathrm{AO}$ captures $\mathrm{h}^{+}$, and IPA captures $\cdot \mathrm{OH}$, therefore, $\mathrm{O}_{2}{ }^{-}$radical is the main active specie, and $\mathrm{h}^{+}$and $\cdot \mathrm{OH}$ are subsidiary in the degradation process.

Based on the above experimental results, the photocatalytic degradation mechanism of $1 \% \mathrm{Cu}-\mathrm{TiO}_{2}$ versus $\mathrm{RhB}$ is proposed in Fig. 13. When $\mathrm{TiO}_{2}$ is exposed to light source, electrons in valence band (VB) are excited to conduction band (CB), producing corresponding holes in VB. The photoinduced electrons in anatase and brookite will transfer to rutile, which accelerates the movement of photoinduced electrons, prolongs the lifetime and inhibits the recombination of photoinduced pairs effectively $[10,17]$. Moreover, the conversion of $\mathrm{Cu}$ ions and the photocatalytic process of $1 \% \mathrm{Cu}-\mathrm{TiO}_{2}$ are as follows $[44,50]$ :

$\mathrm{Cu} / \mathrm{TiO}_{2}+\mathrm{hv} \rightarrow e^{-}+h^{+}$

$\mathrm{Cu}^{2+}+e^{-} \rightarrow \mathrm{Cu}^{+}$

$\mathrm{O}_{2}+e^{-} \rightarrow \cdot 0^{2-}$

$\mathrm{OH}^{-}+h^{+} \rightarrow \cdot \mathrm{OH}$

Consequently, the process of transformation between $\mathrm{Cu}^{2+}$ and $\mathrm{Cu}^{+}$suppresses the recombination of photoinduced pairs, which is in favor of photocatalytic activity. The formed $\cdot \mathrm{O}_{2}{ }^{-}, \mathrm{z} \mathrm{OH}$ radicals and $\mathrm{h}^{+}$ species have strong oxidizing properties and are able to degrade RhB into small inorganic molecules.

\section{Conclusions}

In this work, pure $\mathrm{TiO}_{2}$ and $\mathrm{Cu}-\mathrm{TiO}_{2}$ were synthesized by a hydrothermal process. XRD, Raman and HRTEM results confirm that the anatase/rutile/brookite triphasic structure form in both pure $\mathrm{TiO}_{2}$ and $\mathrm{Cu}-\mathrm{TiO}_{2}$ samples. SEM and TEM images show the particle sizes in the range of $10-20 \mathrm{~nm}$. XPS results confirm that the Ti element exist in the form of $\mathrm{Ti}^{4+}$ and $\mathrm{Cu}$ is present in the $\mathrm{Cu}^{2+}$ and $\mathrm{Cu}^{+}$oxidation states. $\mathrm{Cu}$ doping is beneficial to increase the surface hydroxyl group content of $\mathrm{TiO}_{2}$. PL spectra show that the recombination of photogenerated electrons and holes is inhibited effectively with $\mathrm{Cu}$ addition and the inhibition enhances with the increase of $\mathrm{Cu}$ doping concentration. Pure $\mathrm{TiO}_{2}$ exhibits relatively 
high BET specific surface area $\left(140.8 \mathrm{~m}^{2} / \mathrm{g}\right)$ and $\mathrm{Cu}$ adding can further improve the specific surface area. The pore size distribution curves confirm that the obtained samples are mesoporous materials. RhB solution was employed as the target pollutant and the photocatalytic activity was tested under xenon lamp irradiation. $\mathrm{O}_{2}{ }^{-}$radicals play a major role in the photodegradation process. Triphasic $1 \% \mathrm{Cu}-\mathrm{TiO}_{2}$ shows better photocatalytic property than monophasic/biphasic $1 \% \mathrm{Cu}-\mathrm{TiO}_{2}$. The degradation degree of $1 \% \mathrm{Cu}-\mathrm{TiO}_{2}$ is $93.5 \%$ in $30 \mathrm{~min}$, and the apparent first-order rate constant of $1 \% \mathrm{Cu}-\mathrm{TiO}_{2}$ is $0.091 \mathrm{~min}^{-1}$, suggesting that it is a promising photocatalyst for dye wastewater treatment.

\section{Declarations}

\section{Acknowledgements}

This project was funded by the Applied Basic Research Programs of Sichuan Province (Grant Nos. 2019YJ0664, 2018JY0062), the Chengdu Technology Innovation Research and Development Project of Chengdu City (Grant No. 2019-YFYF-00013-SN) and the Training Program for Innovation of Sichuan Province (S202011079053, CDU-CX-2021527).

\section{References}

1. S.M. Adyani, M. Ghorbani, J. rare Earth. 36, 72-85 (2018)

2. N. Wei, H.Z. Cui, Q. Song, L.Q. Zhang, X.J. Song, K. Wang, Y.F. Zhang, J. Li, J. Wen, J. Tian, Appl. Catal. B-environ. 198, 83-90 (2016)

3. X.D. Zhu, L.X. Pei, R.R. Zhu, Y. Jiao, R.Y. Tang, W. Feng, Sci. Rep. 8, 14249-14257 (2018)

4. D.V. Dao, M.V.D. Bremt, Z. Koeller, T.K. Le, Powder Technol. 288, 366-370 (2016)

5. T.H. Le, A.T. Bui, T.K. Le, Powder Technol. 268, 173-176 (2014)

6. D. Yang, Y.Y. Sun, Z.W. Tong, Y.H. Nan, Z.Y. Jiang, J. Hazard. Mater. 312, 45-54 (2016)

7. A.M. Abdulkarem, E.M. Elssfah, N.N. Yan, G. Demissie, Y. Yu, J. Phys. Chem. Solids 74, 647-652 (2013)

8. V.B.R. Boppana, R.F. Lobo, J. Catal. 281.1, 156-168 (2011)

9. F.C. Correia, M. Calheiros, J. Marques, J.M. Ribeiro, C.J. Tavares, Ceram. Int. 44, 22638-22644 (2018) 10. H.L. Wang, X.Y. Gao, G.R. Duan, X.J. Yang, X.H. Liu, J. Environ. Chem. Eng. 3, 603-608 (2015)

11. Y.F. Zhang, F. Fu, Y.Z. Li, D.S. Zhang, Y.Y. Chen, Nanomaterials. 8, 1032 (2018)

12. Z.L. Yang, J. Lu, W.C. Ye, C.S. Yu, Y.L. Chang, Appl. Surf. Sci. 392, 472-480 (2017)

13. M.R.D. Khaki, M.S. Shafeeyan, A.A.A. Raman, W.M.A.W. Daud, J. Mol. Liq. 258, 354-365 (2018)

14. M.C. Wu, P.Y. Wu, T.H. Lin, T.F. Lin, Appl. Surf. Sci. 430, 390-398 (2018)

15. H. Li, X.J. Shen, Y.D. Liu, L.Z. Wang, J.Y. Lei, J.L. Zhang, J. Alloy. Compd. 646, 380-386 (2015)

16. Y.F. Cao, X.T. Li, Z.F. Bian, A. Fuhr, D.Q. Zhang, J. Zhu, Appl. Catal. B-Environ. 180, 551-558 (2016) 
17. R. Kaplan, B. Erjavec, G. Dražić, J. Grdadolnikc, A. Pintar, Appl. Catal. B-Environ. 181, 465-474 (2016)

18. T. Aguilar, J. Navas, R. Alcántara, C. Fernández-Lorenzo, J.J. Gallardo, G. Blanco, J. Martín-Calleja, Chem. Phys. Lett. 571, 49-53 (2013)

19. Y.P. Zhang, C.X. Pan, J. Mater. Sci. 46, 2622-2626 (2011)

20. L.K. Preethi, T. Mathews, M. Nand, S.N. Jha, C.S. Gopinath, S. Dash, Appl. Catal. B-Environ. 218, 919 (2017)

21. H.Z. Zhang, J.F. Banfield, J. Phys. Chem. B 104, 3481-3487 (2000)

22. V. Uvarov, I. Popov, Mater. Charact. 58, 883-891 (2007)

23. B.K. Mutuma, G.N. Shao, W.D. Kim, H.T. Kim, J. Colloid. Interf. Sci. 442, 1-7 (2015)

24. P.M. Dong, X.D. Cheng, Z.F. Huang, Y. Chen, Y.Z. Zhang, X.X. Nie, X.W. Zhang, Mater. Rsc. Bull. 97, 8995 (2018)

25. X.J. Yang, S. Wang, H.M. Sun, X.B. Wang, J.S. Lian, T. Nonferr. Metal. Soc. 25, 504-509 (2015)

26. J.L. Li, X.T. Xu, X.J. Liu, C.Y. Yu, D. Yan, Z. Sun, L.K. Pan, J. Alloy. Compd. 679, 454-462 (2016)

27. O. Avílés-García, J. Espino-Valencia, R. Romero, J.L. Rico-Cerda, M. Arroyo-Albiter, R. Natividad, Fuel. 198, 31-41 (2017)

28. Z.M. Wang, B. Liu, Z.X. Xie, Y.M. Li, Z.Y. Shen, Ceram. Int. 42, 13664-13669 (2016)

29. G. Córdoba, M. Viniegra, J.L.G. Fierro, J. Padilla, R. Arroyo, J. Solid State Chem. 138, 1-6 (1998)

30. R. Bashiri, N.M. Mohamed, C.F. Kait, S. Sufian, M. Khatani, J. Environ. Chem. Eng. 5, 3207-3214 (2017)

31. M. Shaban, A.M. Ashraf, M.R. Abukhadra, Sci. Rep. 8, 781 (2018)

32. J. Tauc, R. Grigorovici, A. Vancu, Phys. Status Solidi B 15, 627-637 (1966)

33. P. Makal, D. Das, Appl. Surf. Sci. 455, 1106-1115 (2018)

34. Y.Z. Wang, Y.S. Wu, H. Yang, X.X. Xue, Z.H. Liu, Vacuum. 131, 58-64 (2016)

35. J. Singh, A.K. Manna, R.K. Soni, J. Mater. Sci-Mater. El. 30, 16478-16493 (2019)

36. X. Fan, J. Wan, E.Z. Liu, L. Sun, Y. Hu, H. Li, X.Y. Hu, J. Fan, Ceram. Int. 41, 5107-5116 (2015)

37. X.F. Lei, X.X. Xue, H. Yang, Appl. Surf. Sci. 321, 396-403 (2014)

38. B. Appavu, S. Thiripuranthagan, Visible active N. J. Photoch. Photobio. A 340, 146-156 (2017)

39. B.K. Kaleji, S. Mirzaee, S. Ghahramani, S. Rezaie, N. Hosseinabadi, A. Fujishima, J. Mater. Sci-Mater.

El. 29, 12351-12359 (2018)

40. C.P. Sibu, S.R. Kumar, P. Mukundan, K.G.K. Warrier, Chem. Mater. 14, 2876-2881 (2002)

41. T. Ali, A. Ahmed, U. Alam, I. Uddin, P. Tripathi, M. Muneer, Matrer. Chem. Phys. 212, 325-335 (2018)

42. S. Sood, A. Umar, S.K. Mehta, S.K. Kansal, J. Colloid Interf. Sci. 450, 213-223 (2015)

43. X.X. Lin, F. Rong, D.G. Fu, C.W. Yuan, Powder Technol. 219, 173-178 (2012) 
44. V. Krishnakumar, S. Boobas, J. Jayaprakash, M. Rajaboopathi, B. Han, M. Louhi-Kultanen, J. Mater. Sci-Mater. El. 27, 7438-7447 (2016)

45. X.D. Zhu, R.R. Zhu, L.X. Pei, H. Liu, L. Xu, J. Wang, W. Feng, Y. Jiao, W.M. Zhang, J. Mater. Sci-Mater. El. 30, 21210-21218 (2019)

46. Z.H. Fan, F.M. Meng, J.F. Gong, H.J. Li, Z.L. Ding, B. Ding, J. Mater. Sci-Mater. El. 27, 11866-11872 (2016)

47. Y. Zhang, T. Wang, M. Zhou, Y. Wang, Z.M. Zhang, Ceram. Int. 43, 3118-3126 (2017)

48. J. Li, Y.J. Wan, Y.J. Li, G. Yao, B. Lai, Appl. Catal. B-Environ. 256, 117782 (2019)

49. J.X. Qin, J. Wang, J.J. Yang, Y. Hu, M.L. Fu, D.Q. Ye, Appl. Catal. B-Environ. 267, 118667 (2020)

50. H.W.P. Carvalho, M.V.J. Rocha, P. Hammer, T.C. Ramalho, J. Mater. Sci. 48, 3904-3912 (2013)

\section{Figures}

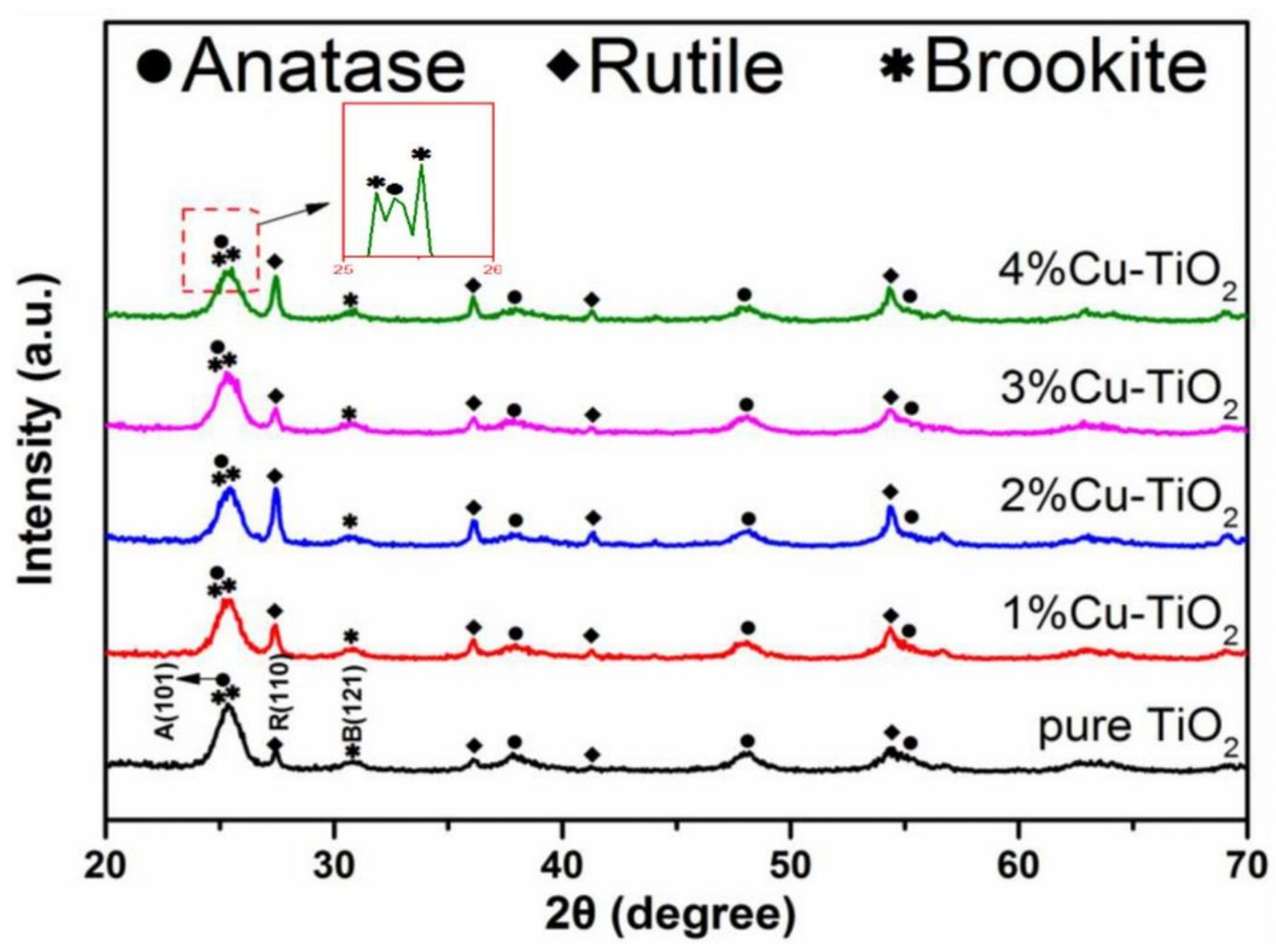

Figure 1

XRD patterns of pure $\mathrm{TiO} 2$ and $\mathrm{Cu}-\mathrm{TiO} 2$. 


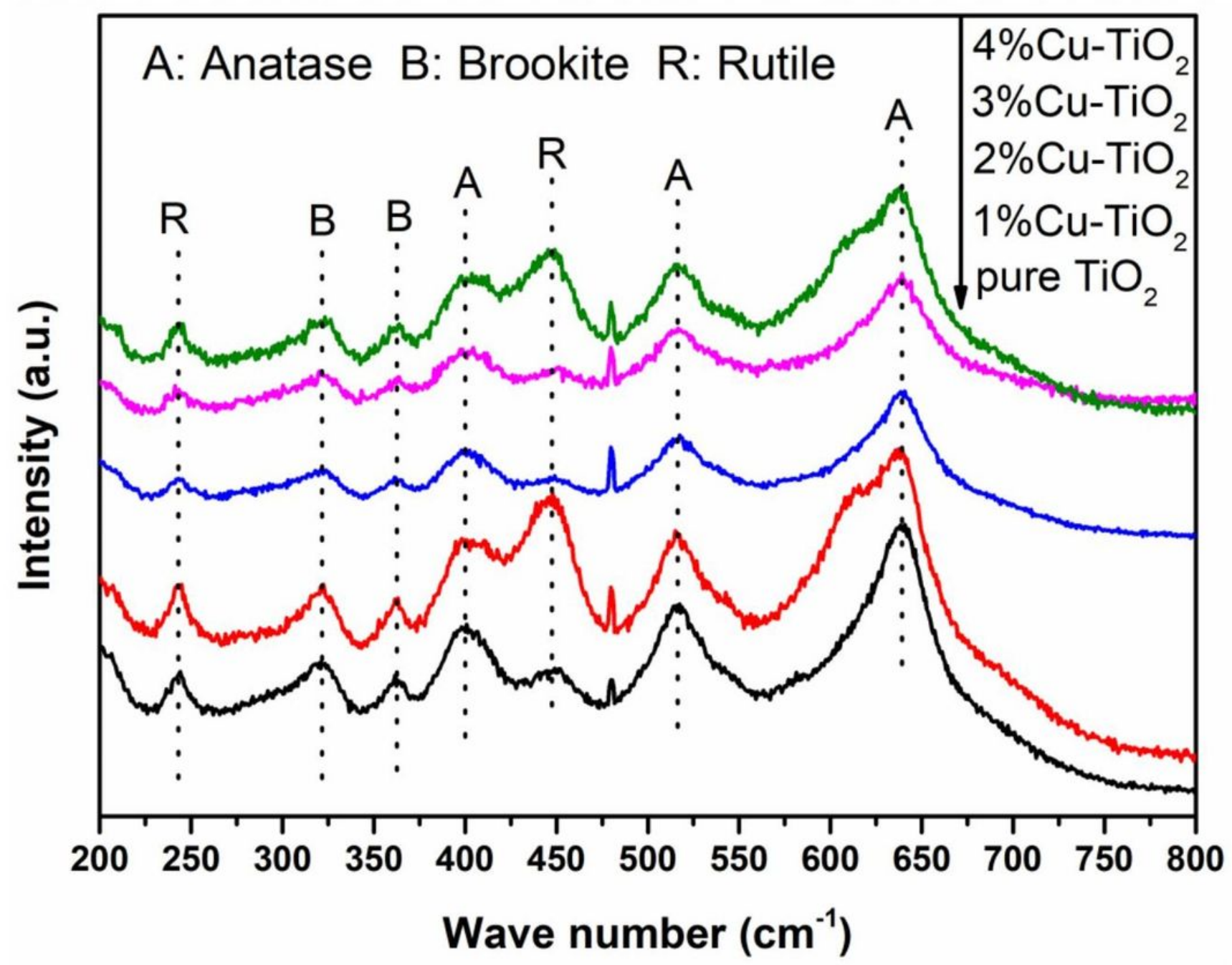

Figure 2

Raman spectra of pure $\mathrm{TiO} 2$ and $\mathrm{Cu}-\mathrm{TiO} 2$. 


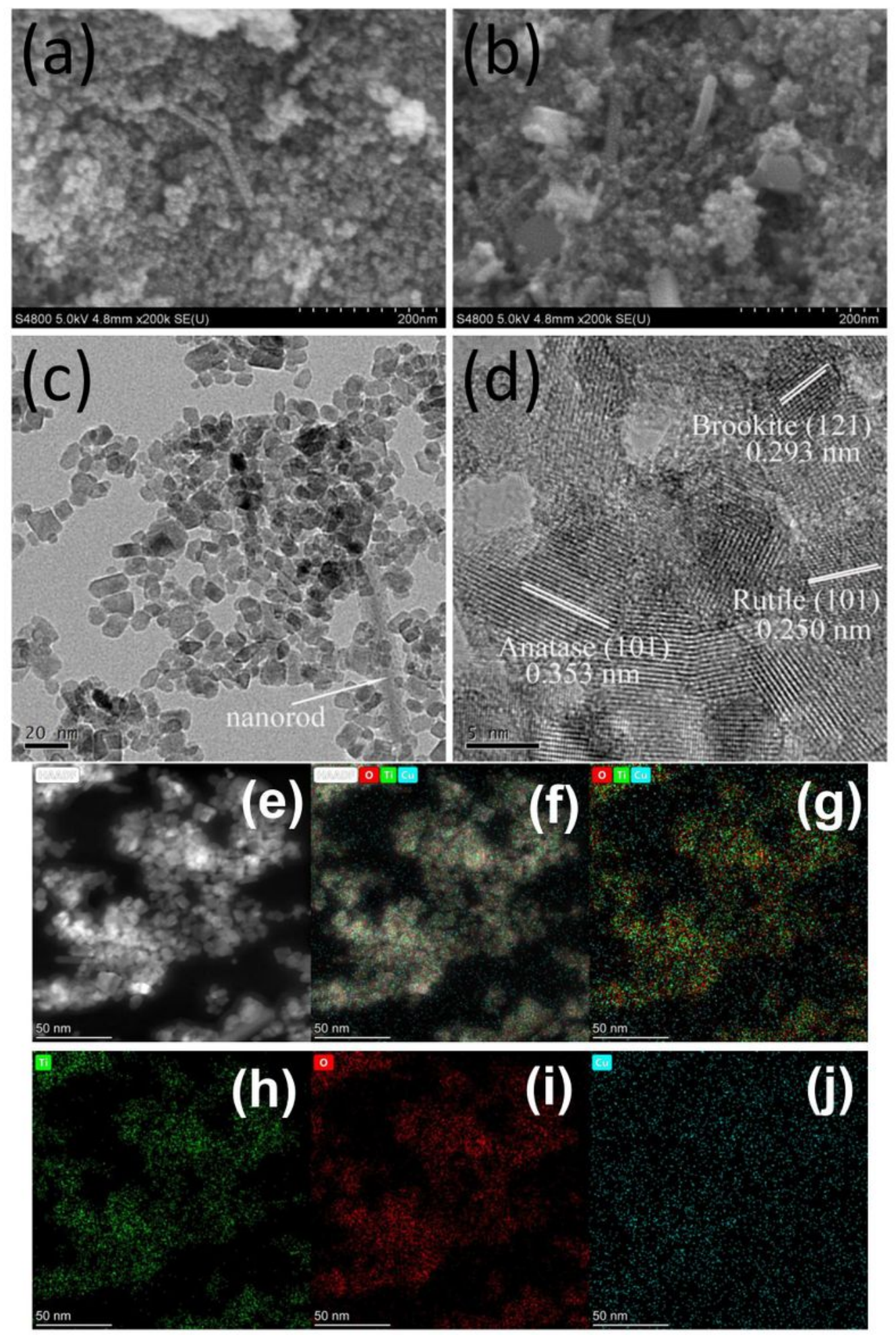

Figure 3

(a) SEM images of pure TiO2, (b) SEM images of $1 \% \mathrm{Cu}-\mathrm{TiO} 2$, (c) TEM image of $1 \% \mathrm{Cu}-\mathrm{TiO} 2$, (d) HRTEM image of $1 \% \mathrm{Cu}-\mathrm{TiO} 2$ and $(\mathrm{f}-\mathrm{j}) \mathrm{STEM}$ mapping of $1 \% \mathrm{Cu}-\mathrm{TiO} 2$ 

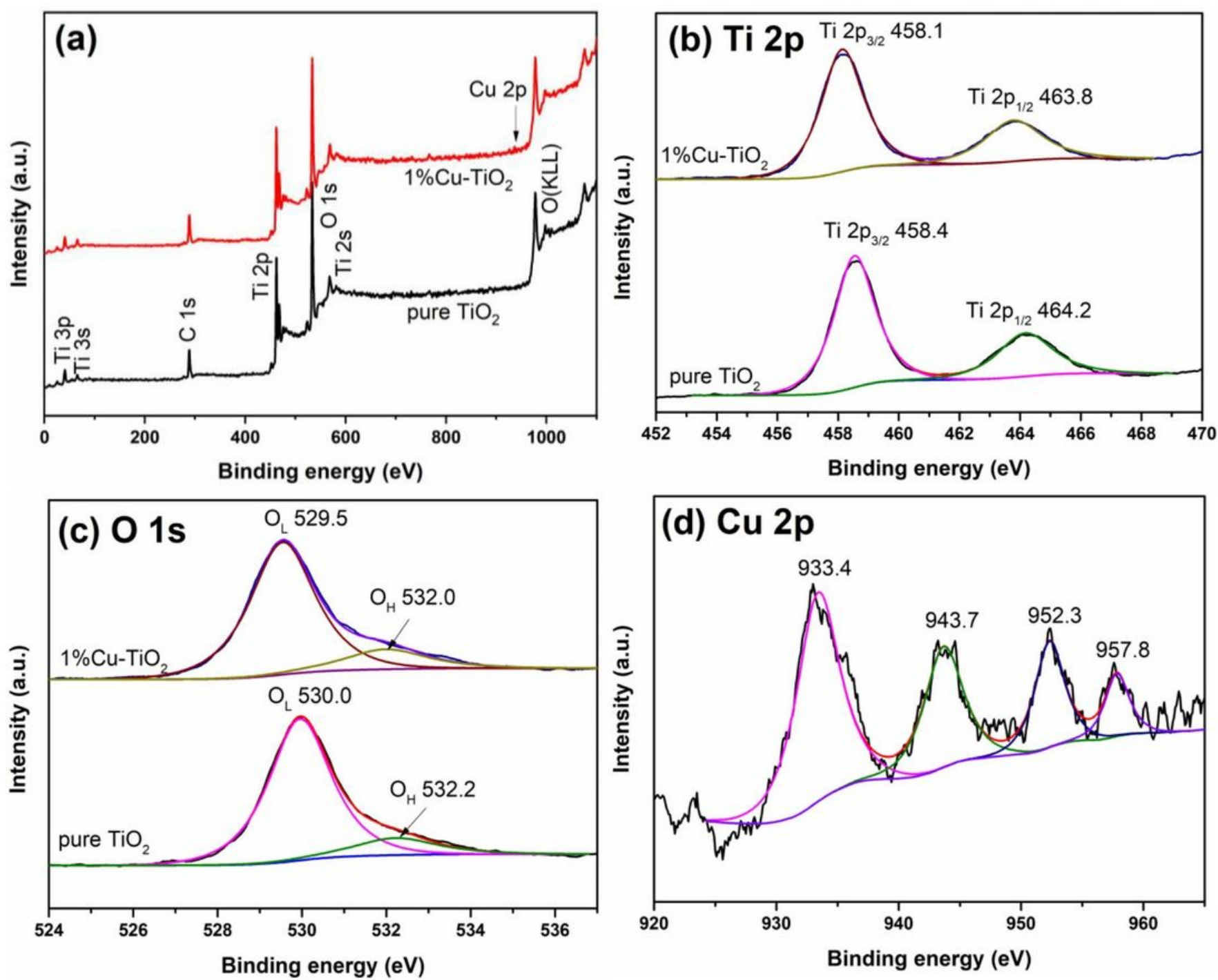

Figure 4

XPS spectra of pure $\mathrm{TiO} 2$ and $1 \% \mathrm{Cu}-\mathrm{TiO} 2$. 

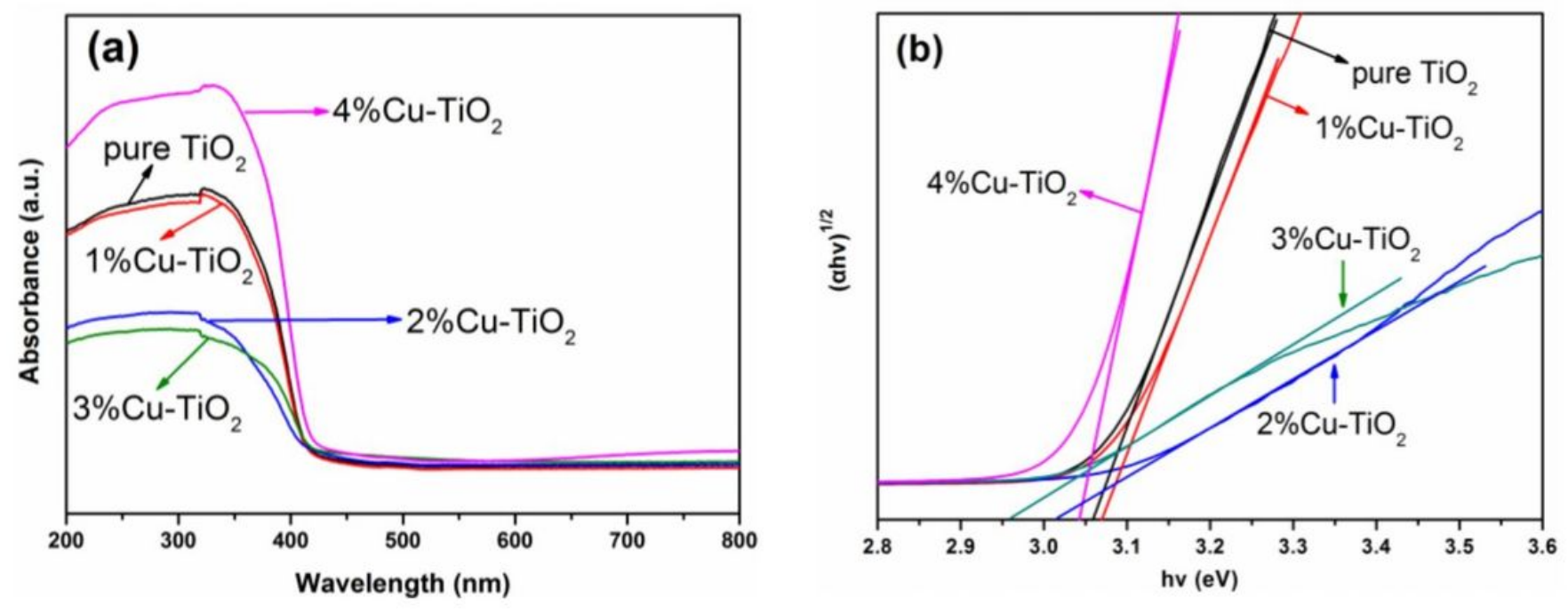

\section{Figure 5}

(a) Diffuse refection spectra of pure $\mathrm{TiO} 2$ and $\mathrm{Cu}-\mathrm{TiO} 2$, (b) plots of (ahv) $1 / 2$ versus the photon energy (hv). 


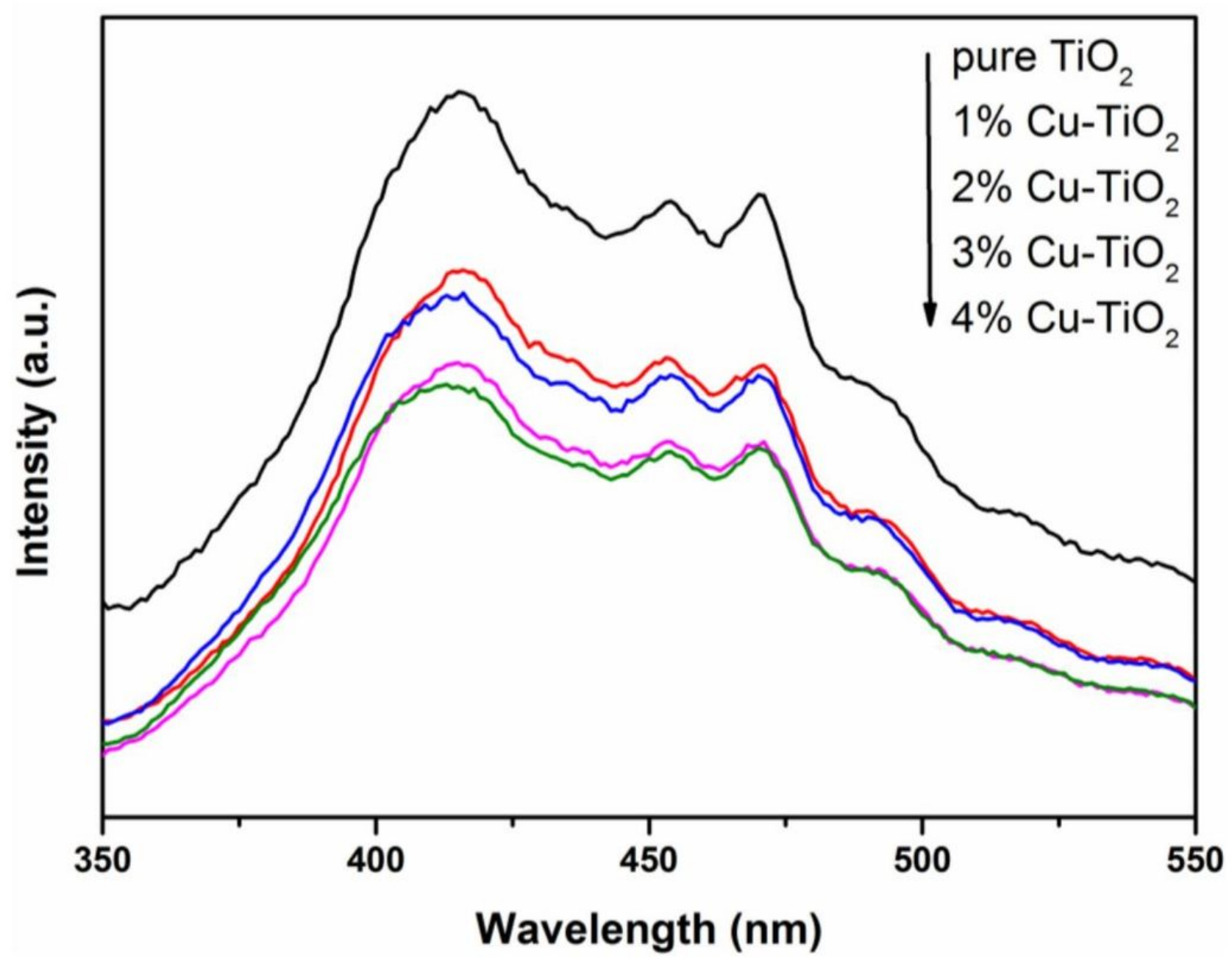

Figure 6

Photoluminescence (PL) spectra of pure $\mathrm{TiO} 2$ and $\mathrm{Cu}-\mathrm{TiO} 2$. 

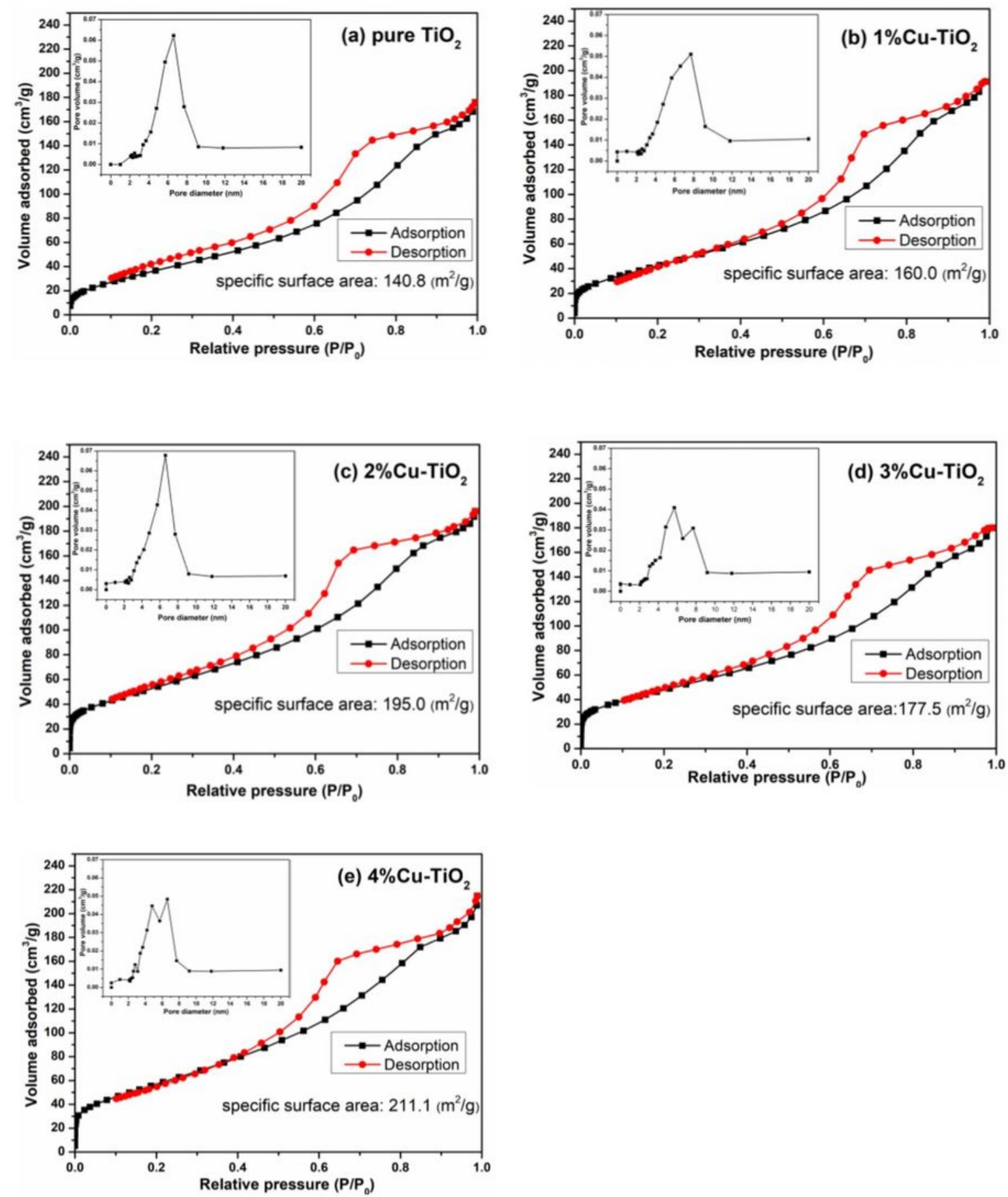

\section{Figure 7}

Nitrogen adsorption-desorption isotherms and pore size distribution curves of (a) pure TiO2, (b) $1 \% \mathrm{Cu}-$ TiO2, (c) 2\%Cu-TiO2, (d) 3\% $\mathrm{Cu}-\mathrm{TiO} 2$ and (e) $4 \% \mathrm{Cu}-\mathrm{TiO} 2$ 

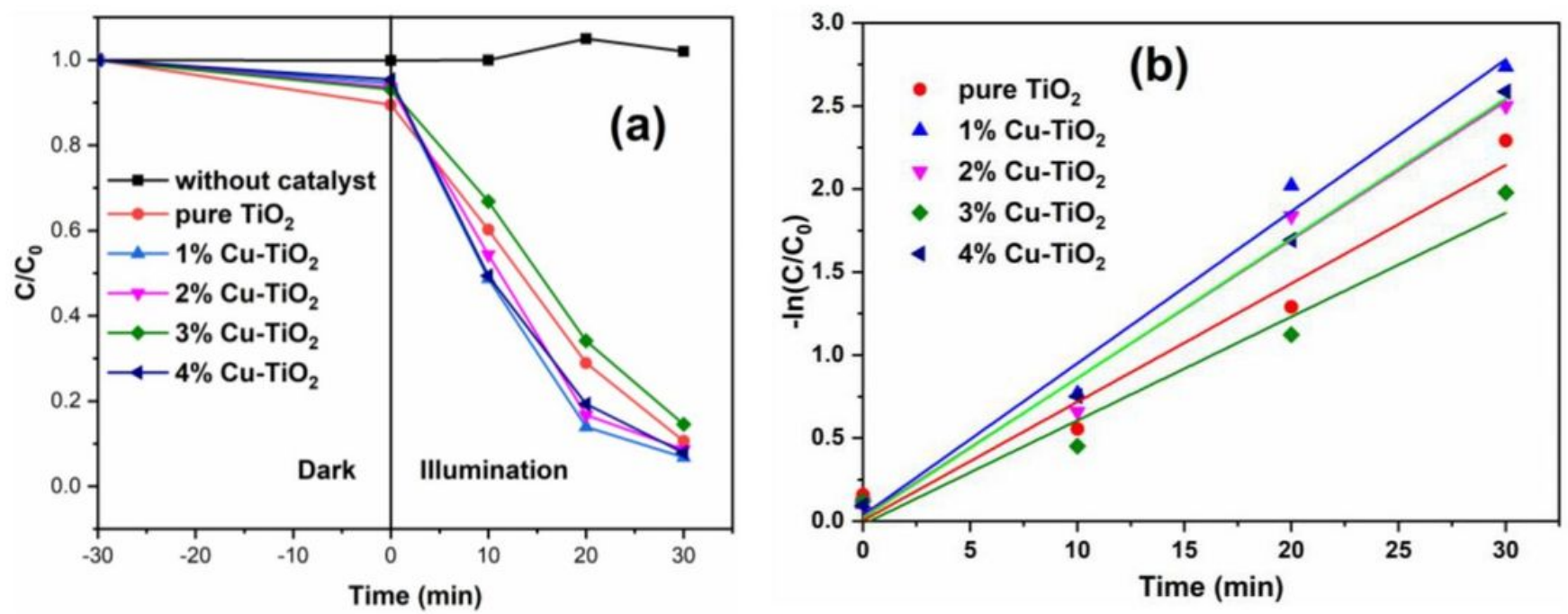

Figure 8

(a) Photocatalytic degradation of $\mathrm{RhB}$ for pure $\mathrm{TiO} 2$ and $\mathrm{Cu}-\mathrm{TiO} 2$, (b) degradation kinetics curves of photocatalysts on RhB.
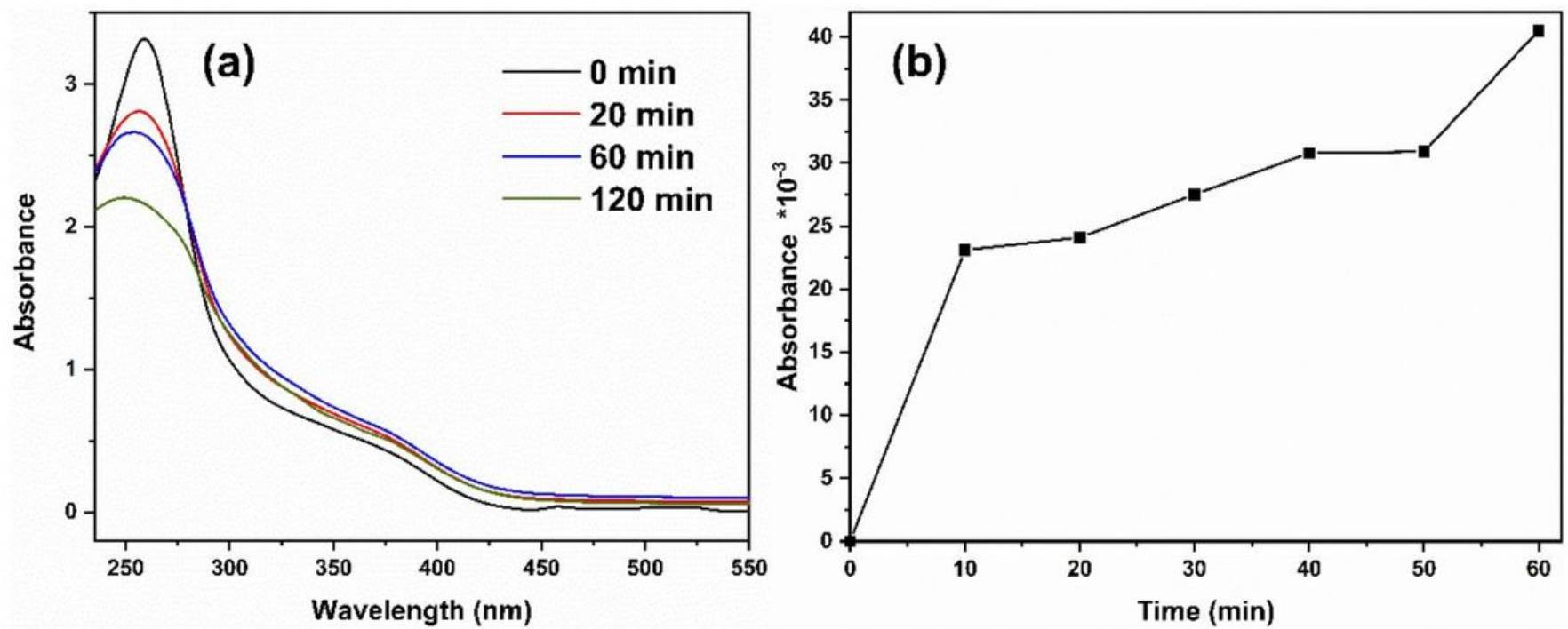

Figure 9

The absorbance curves of NBT (a) and 2, 3-HBA (b) of $1 \% \mathrm{Cu}-\mathrm{TiO} 2$ 

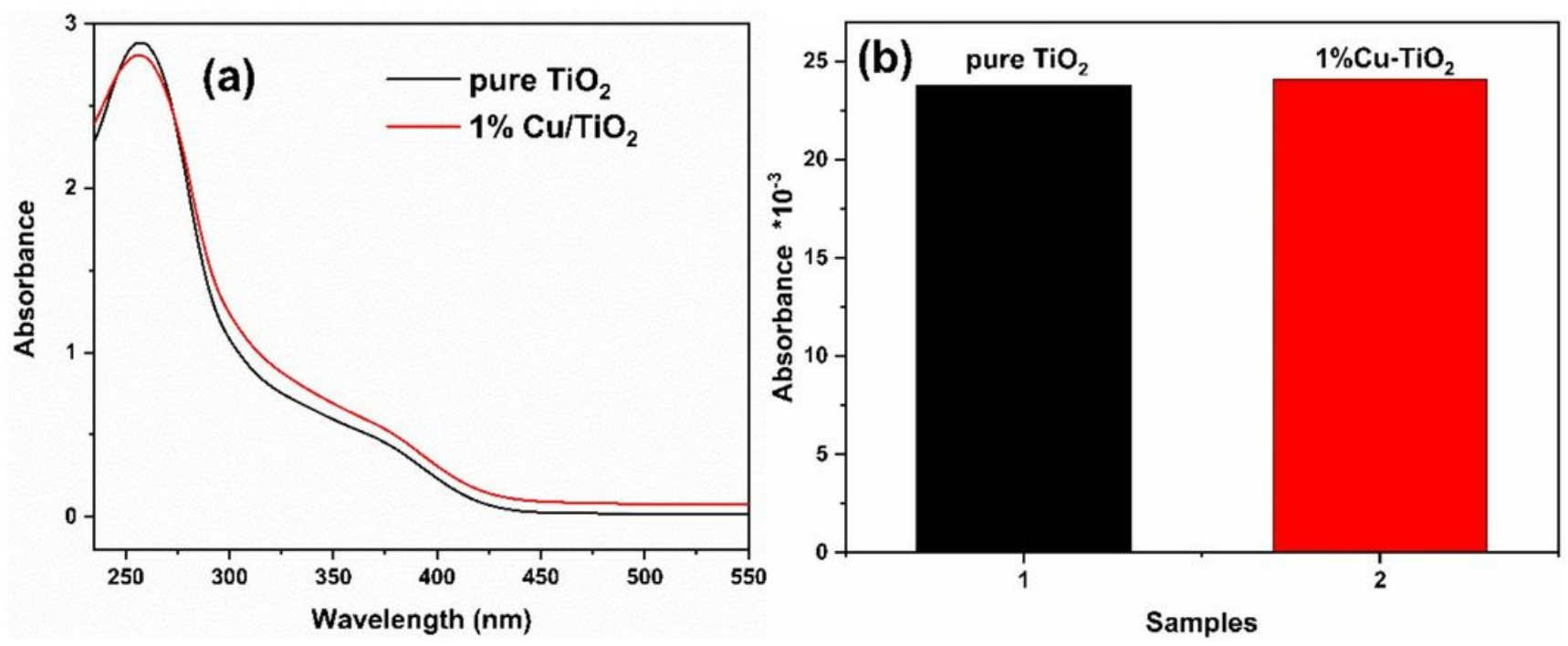

Figure 10

NBT (a) and 2, 3-HBA (b) absorbances of $1 \% \mathrm{Cu}-\mathrm{TiO} 2$ and pure $\mathrm{TiO} 2$
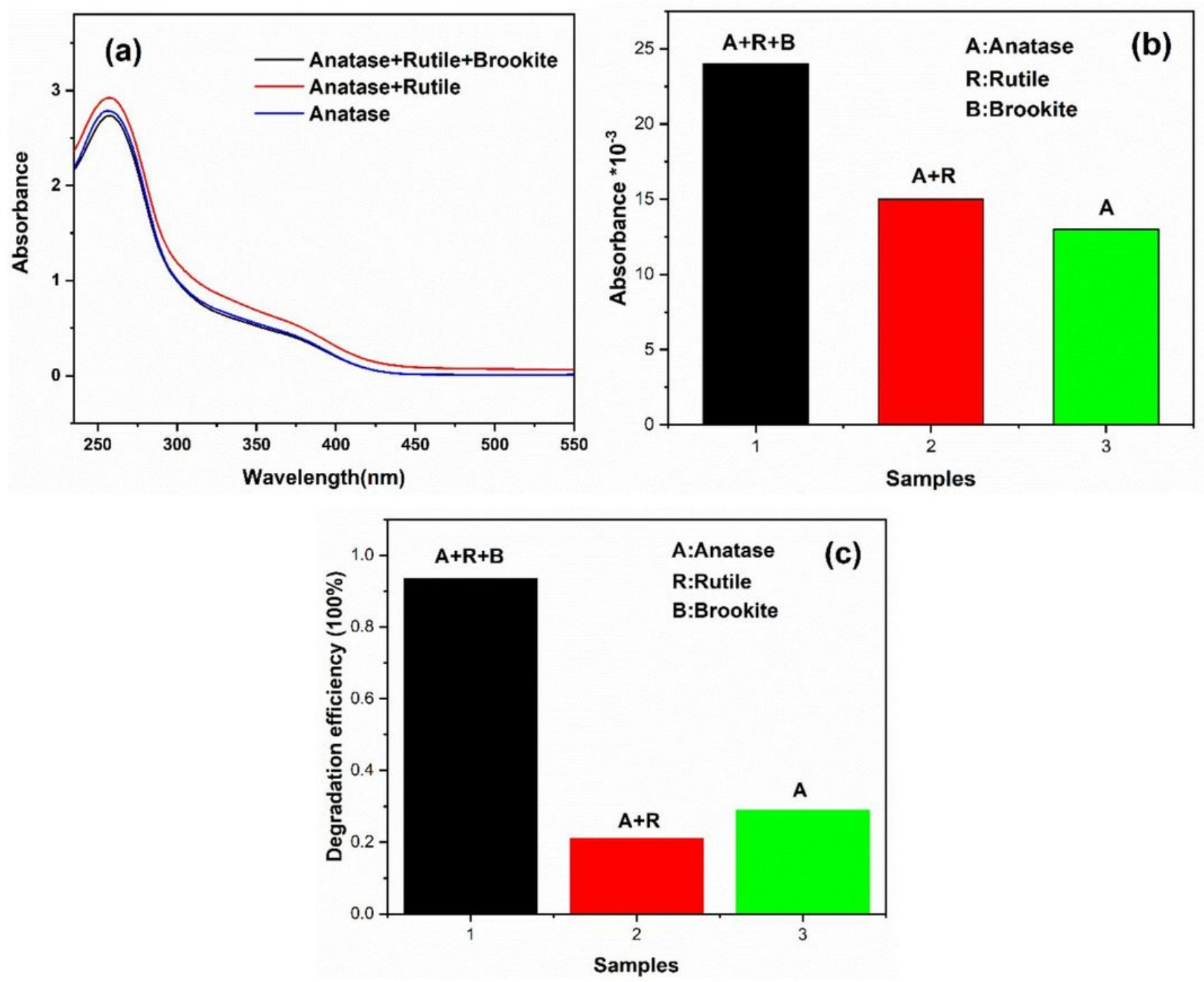

Page $22 / 24$ 
Figure 11

NBT (a) and 2, 3-HBA (b) absorbances and degradation efficiency (c) of $1 \% \mathrm{Cu}-\mathrm{TiO} 2$ with different phase structure

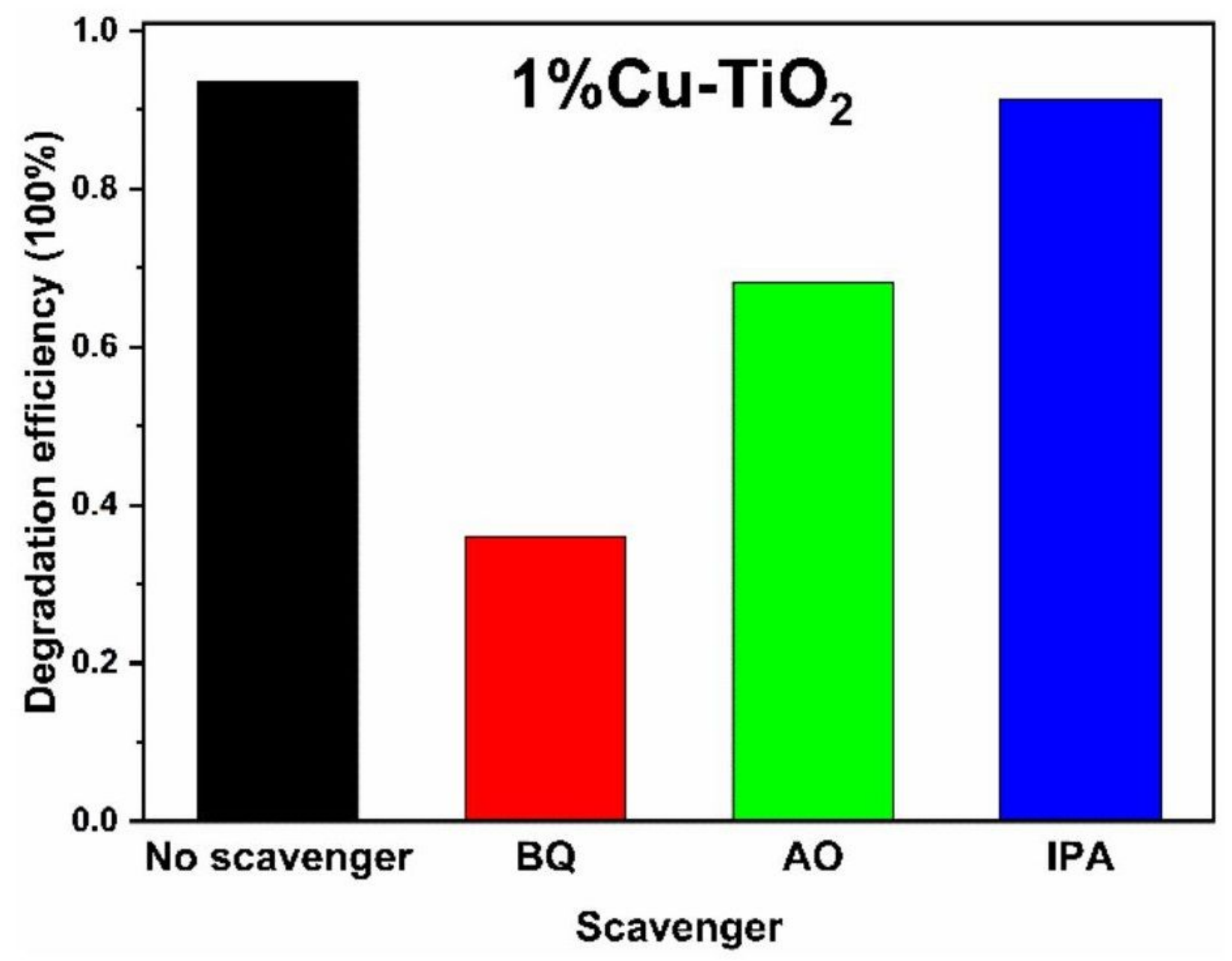

Figure 12

The degradation rate of $1 \% \mathrm{Cu}-\mathrm{TiO} 2$ in the presence of different scavengers 


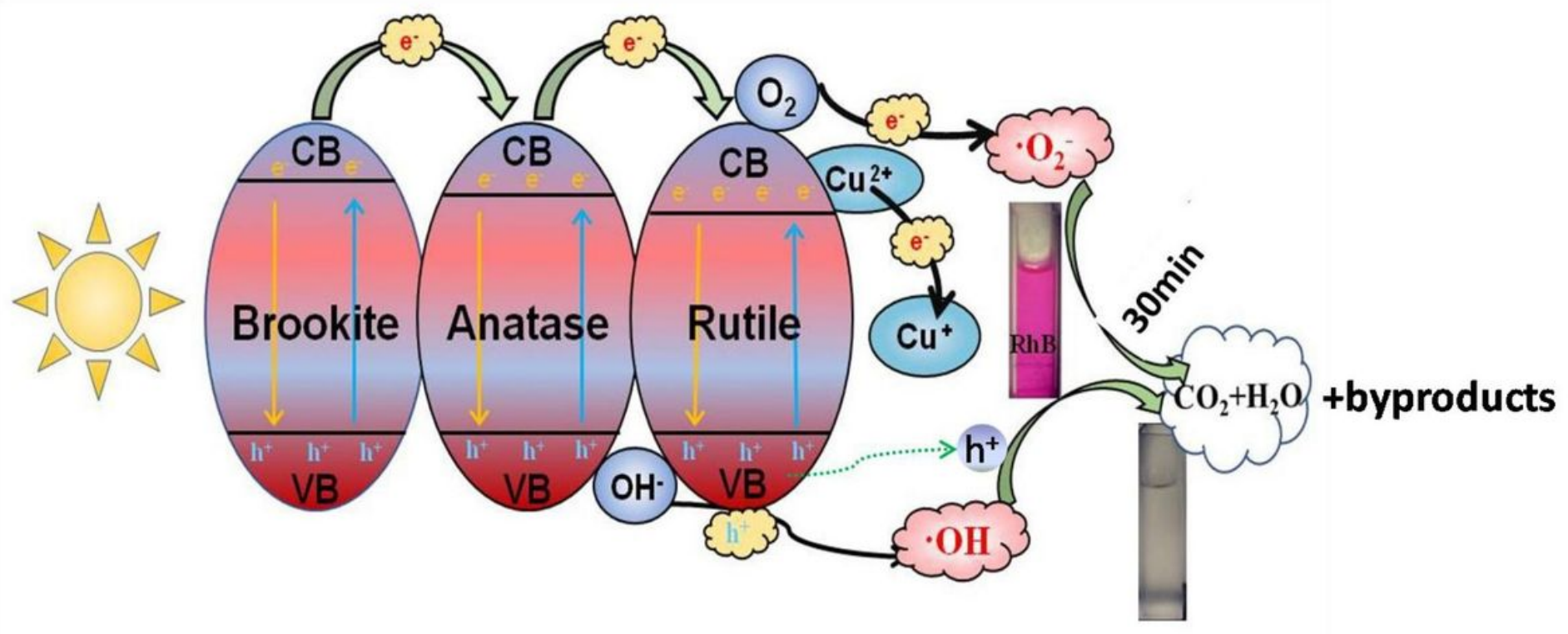

Figure 13

Schematic diagram of charge transfer and photodegradation of $\mathrm{RhB}$ for $1 \% \mathrm{Cu}-\mathrm{TiO} 2$ 